\title{
PERFORMANCE MEASUREMENT: A STAKEHOLDER APPROACH ${ }^{1}$
}

\author{
Niki Lukviarman \\ Faculty of Economics, Andalas University \\ E-mail: lukviarman@fekon.unand.ac.id
}

\begin{abstract}
It is important that companies maintain their contractual relationships with their stakeholder groups. Therefore, a company's strategy needs to accommodate these relationships and, consequently, there is a need for appropriate performance measurement to determine how well the company serves its stakeholders. Based on a literature review, this paper seeks to observe current performance measurement models from the view of stakeholder theory. Although broader performance measurement models have been introduced in response to the existence of stakeholders, these models still rely on financial indicators as primary measures whilst using operational indicators as complementary measures. However, these measures have recognized the importance of business performance not only to measure current outcomes, but also to influence future outcomes. Problems in implementing broader measures of performance include identification of relevant variables, relating action and results, and translation of projects and activities into measurable terms.
\end{abstract}

Keywords: stakeholder, performance measurement, maintaining quality

\section{INTRODUCTION}

Organizations and companies in particular, are facing pressures for change which require them to provide adequate responses in order to survive and succeed in today's business competition. Responses are generated by management who are required to provide enhanced performance whilst improving and maintaining quality, remaining competitive and sufficiently flexible to meet the next pressure for change (Broadbent, 1999). One of these environment changes is increasing pressure from the broader and more demanding stakeholder groups, whose demands are now being integrated into business processes (Waterhouse and Svendsen, 1998). As a result, corporations need to go beyond traditional strategic management issues by considering the envi- ronment for those external, internal, and interface stakeholders that are likely to influence the organization's decisions. Consequently, strategic-decision making is becoming more complex as the impact of a dynamic company's environment interacts with different stakeholder expectations.

For a long time, early models of performance measurement focused solely on financial measures, which work well for the industrial era (Kald and Nilsson, 2000; Keasey et al, 2000; Kaplan and Norton, 1992; Eccles, 1991). The emergence of the information era in the last decades of the twentieth century made obsolete many of the fundamental assumptions of industrial era competition (Kaplan and Norton, 1996). Today organizations are competing in complex environments which require them to

\footnotetext{
${ }^{1}$ Part of this articel have been presented at the "Integrated Business Strategy Seminar" of Graduate School of Business, Curtin University of Technology-Australia (December 2000).
} 
consider new capabilities for competitive success. As a corollary, Kaplan and Norton (1996, p.3) believe that "the ability of a company to mobilize and exploit its tangible or invisible assets has become more decisive than investing and managing physical assets, tangible assets". Unfortunately, financial reporting-based measures did not cover the valuation of a company's intangible and intellectual assets that generate future growth, which are critical for success in today's and tomorrow's competitive environment (Olve et al, 2000). Hence, other performance measures that can cover broader matters and have the capabilities to navigate the organizations to future competitive success are required.

This paper argues that there is a need for Performance Measurement (PM) which provides the framework for a strategic measurement and management system from the perspective of stakeholder theory. It addresses issues relating to the changing nature of PM and discusses a broader PM system, with the inclusion of important relationships between a company and its stakeholders, rather than solely traditional-financial measurement. Based on this view, companies are defined as a nexus of contracts (Jensen and Meckling, 1976), and are engaged in an interdependent symbiotic relationship with their stakeholders (Waterhouse and Svendsen, 1998). Since important aspects of contractual relationships will have an affect on the entire business process, business performance in this paper will be viewed from a strategic management perspective.

This paper begins with the importance and the changing nature of the PM system, followed by a review of the theory of performance, which will discuss the concept and domain of PM, and the development of various models. The paper then discusses stakeholder theory, and relates this approach to the strategic management point of view, followed by a review of methods in identifying relevant stakeholder groups. In the last section, this paper will discuss PM from a stakeholder perspective, followed by implications for future research, and make some conclusions.

\section{THE IMPORTANCE OF PERFORMANCE MEASUREMENT}

PM systems have historically developed as a means of monitoring and maintaining organizational control (Brignall and Ballantine, 1996), in order to ensure the achievement of organizational goals and objectives. Therefore, PM reflects "organizational culture and philosophy, and describes how well work is done in terms of cost, time and quality" (Tatikonda and Tatikonda, 1998, p. 49). Through an appropriate PM system, an organization can monitor the implementation of its plans to determine how successful they are, and how to improve them.

From the strategic management point of view, the importance of PM can be seen at all stages (Kald and Nilsson, 2000; Atkinson et al, 1997; Eccles, 1991). In designing strategies, PM will contribute to guidelines, to help set standards and targets for strategic direction. At the implementation stage, PM systems will be used to track progress, communicate strategies, and motivate and influence people in the organization to achieve targets. Moreover, the PM systems can contribute to the evaluation of the quality of strategic decisions that have been made and help determine how to improve them, in order to reinforce new competitive strategies. As a result, the PM system will have an impact on the ability of the firm to sustain its competitiveness, as well as its ability to meet environmental changes. In the absence of appropriate measures of performance, the company cannot track its business progress, nor identify its areas of strength and weakness in order to design its strategy in the future. Therefore, Kald and 
Nilsson (2000) argue the importance of strategy, actions and measures within the company should be mutually consistent.

\section{Traditional Performance Measurement System}

Early models of PM focused solely on financial-accounting measures, and this 'formal' PM system (Atkinson et al, 1997) is an extension of the company's financial reporting systems. Financial performance indicators remained the single most important performance measurement until 1980s (Ghalayani and Noble, 1996). In the late 1980s, performance studies flourished, as it was hoped that overall effectiveness measures could be constructed as a result of changes in the world market (Meyer and Gupta, 1994; Ghalayani and Noble, 1996). In fact, the current interest in the performance construct is on the critical role of PM systems in maintaining an organization's competitive position (D'Souza and Williams, 2000). Within this context it might be argued that continuing development of PM is necessary for any further improvement to accommodate the changing environment in the future, as well as reflecting more appropriate PM models.

Finance-based PM is considered to be the 'traditional PM system' that has been claimed to measure "too many things and the wrong things" (Atkinson, et al, 1997, p.25). The corollary of this is that this model has been of little help in measuring performance in the new competitive environment (Chow et al, 1997), as a result of its backward-looking focus (Jesuthasan et al, 2000). Several researchers have also provided their arguments on the shortcomings of such a measurement system. Critics of the use of traditional performance systems as the only bases in judging business performance can The Changing Nature of the Performance Measurement System be seen in appendix 1. Despite differences in these arguments, limitations of traditional PM can be classified into two categories (Ghalayani and Noble, 1996, p.64): "general limitations due to overall characteristics and limitations specific to certain traditional performance measures such as productivity or cost".

However, researchers on PM have not agreed to disregard financial measures within the PM systems, because they argue that financial measures are legitimate and important indicators (Eccles and Pyburn, 1992; Jesuthasan et al, 2000), and necessary as long as measures of residual claims are required for legal economic reasons (Waterhouse and Svendsen, 1998). Indeed Chow et al (1997, p.22) argue that "financial measures should be retained and viewed in the larger context of the company's competitive strategies for creating future value". In short, these arguments suggest that the appropriate PM system is the one that does not emphasize financial measures alone.

In addition, managers should not have to choose between financial and nonfinancial measurement (Kaplan and Norton, 1992), and they should not be viewed as substitutes for each other (Epstein and Manzoni, 1997). Accordingly, Kaplan and Norton (1992, p.72) state that "no single measure can provide a clear performance target of focus attention on the critical areas of the business'. Although financial indicators are important, these measures are the result of past performances and inadequate for guiding and evaluating the company to create future value. Therefore, it might be better to consider additional measures of current performance as indicators of future performance to properly monitor a company's progress.

As the economy becomes globalized, the market instigates corporate environmental changes, promoting stiffer and 
more complex competition. Consequently, a number of new techniques for organizing and managing companies have been introduced (Dent, 1996). In order to enable corporations to respond to opportunities and challenges faced in their market environment, they have to consider and reinforce new competitive strategies. A clear and focussed strategy allows the company to design its performance measurement and evaluation system to concentrate the manager's attention on the strategy's key success factors (Epstein and Manzoni, 1997; Atkinson and Epstein, 2000). Thus, in a dynamic environment, it is essential for the company to keep performance measures current and relevant.

Some measures describing business performance cannot dominate for long and may shift dramatically over time. This is because such performances lose usefulness as a result of declining in their ability to discriminate 'good from bad' performance (Meyer and Gupta, 1994). Moreover, a dynamic environment requires companies to make more complex strategic decisions, where the outcomes extend over a longer period (Waterhouse and Svendsen, 1998) and requiring different and more dynamic measures. Consequently, relying on traditional finance-based performance measured systems has failed to supply the information necessary to elicit strong future performance from the organization.

The need for the companies to change to a PM that is relevant to current development in business environment is undoubtedly important. Dixon et al. (1990) argue that in order for companies to compete with industry leaders, they have to change their ways of measuring performance. Additionally, in order to be effective, performance measures need to reflect the changes in competitiveness (Tatikonda and Tatikonda, 1998) and the fact that there are continuous of change in the dominant measures
(Meyer and Gupta, 1994). Some arguments from researchers on the need to change PM system, apart from financial-based PM, are described in appendix 2. In general it might be argued that navigating the company into a more competitive, technological, and capability-driven future, cannot be accomplished merely by monitoring and controlling financial measures of past performance.

Based on this serious dissatisfaction with financial measures and the need for a much broader PM system, many researchers (see appendix 2) urge the development and improvement of PM. However, the objective of broadening PM is not simply to include non-financial indicators to measure outcomes that cannot be covered by financial measures. A more fundamental reason is the need to incorporate factors in PM that will determine or influence future outcomes and could balance various indicators of measurement (Olve et al, 2000). Thus, it is expected that PM should also consist of important indicators that could be used as the drivers of a company's future performance and emphasize the actions necessary for long-term success.

The need to supplement financial measurement with others that cover broad business matters brings us to the issue of which areas need to be considered. This issue is deemed important since business aspects are so broad and all of them could seem equally important. As a corollary, a further issue in its operationalization is how to cover such broad areas, make them measurable and balance, in order to achieve the objectives of PM. In short, it is significant to consider the broader-set of measurement systems, without losing the focus and objectives of business performance measures.

Chakravarthy (1986) argues that organizational performance and organizational effectiveness are two of the labels under which aspects of strategic performance should be measured. However, he 
believes that there is little agreement on how performance should be measured. Several researchers, in regard to the aspects that should be considered in developing broad performance measurement, provide their arguments, as can be seen in appendix 3. In summary, it can be argued that such broader PM should include a 'mix and balance' of financial and non-financial (operational) measures as well as reflecting companies' contribution to their stakeholder groups.

Based on the factors to be considered in developing a broader-set of criteria for a PM system, it might be argued that such PM is the system that is designed to accommodate and satisfy the diverse interests of stakeholders. Consequently, there is a tendency to depart from solely traditionalfinancial measurement systems, which emphasize maximization of shareholders' value. Therefore, the attempts to measure satisfaction of all of the firm's stakeholders are important. Indeed, the intention to include the measurement of various interests of stakeholder expectations could be seen as discriminators of strategic performance (Chakravarthy, 1986). In brief, the pressure towards broadening a company's accountability from stockholders alone, to include interests of other stakeholder groups, is obvious.

\section{THE THEORY OF PERFORMANCE The Key Properties of Performance Meas-} urement

Performance indicators should reflect the impact that a modern organization has on the world around it and how it is perceived. Atkinson and Epstein (2000), argue that companies must refrain from adding too many measures in their PM system. These writers also believe that there is a longstanding tradition that a performance measure should have three attributes, namely be complete, be measurable, and be controllable (p.27). These attributes provide insights in the development and the implementation of every PM system.

In addition, Meyer and Gupta (1994) believe that one purpose of organizational design is to promote comparability and variability, and therefore both of them are key properties of any performance measures. Accordingly, they argue that comparability is 'the extent to which a measure is valid across several settings', and variability is a 'measure's capacity to capture a range of performance outcomes' (p.310). Therefore, PM requires comparability and yet should exhibit variability in order to discriminate between good and bad performers. As a result, one might argue that if a specific PM has lost these key properties, it has already lost its usefulness in providing adequate measures to differentiate between high and low performers.

Moreover, Meyer and Gupta (1994) argue that many measures are running down because they lose variability and hence their capacity to measure performance. Therefore, such measures will tend to be less proactive indicators of potential business problems (Epstein and Manzoni, 1997) and can no longer meet their objectives. According to Meyer and Gupta (1994, pp.331-347) there are many forces which tend toward the running down of a PM by driving out variability. Four of them are positive learning, preserve learning, selection, and suppression. However, Meyer and Gupta (1994) argue that aside from those factors, external conditions can also induce variability into performance measures. Therefore, they argue that changes in environments may have an effect on existing performance measures. In line with this argument, Broadbent (1999) believes that the environment is of growing importance and will become part of the developing agenda of PM. In summary, it is clear that comparability and variability are the important key properties in any performance measures. Hence, any changes in PM 
should consider the importance of these properties.

The Domain of Performance Measurement The important issue to be addressed in the discussion of PM is to delineate the domain of performance concept (Venkatraman and Ramanujam, 1986). From the view of strategic management, they argue that the PM concept can be differentiated using three domains (p.803), as follows:

- Domain of financial performance, which is the narrowest concept of business performance by using simple outcome-based financial indicators that are assumed to reflect the fulfilment of the economic goals of the firm. This approach remains very much financial in its orientation and assumes the dominance and legitimacy of financial goals in a firm's system of goals.

- Domain of financial and non-financial (operational) performance as a broader conceptualisation of business performance that include emphasis on operational performance in addition to indicators of financial performance. This approach seems to focuses on key operational success factors that might lead to financial performance.

- Domain of organizational effectiveness, which are predominantly used if the multiple and conflicting nature of organizational goals and the influence of multiple constituencies or stakeholders are superimposed.

Although a broader conceptualisation of PM is welcomed, Venkatraman and Ramanujam (1986) argue that there is a considerable debate on the use of the organizational effectiveness domain as a broader concept among those three. However, despite the fact that each of these domains is a subset of the overall concept of organizational effectiveness (with financial domain as the core domain), they argue that most strategy studies have restricted their focus to the first two. They believe that this tendency is due to the availability of data and their implications for operationalization. This argument is supported by Kald and Nilsson (2000) who state the difficulties in using a broader-set of PM criteria in translating programs and activities to be measurable. Therefore one might argue that the operationalization and benefit of PM system in the organizational context are important issues in designing PM.

\section{The Development of Various Models}

The PM system is needed to measure the achievement of a company's objectives resulting from strategy implementation and decision-making processes. In considering the stakeholder model in designing a company's strategies, corporate goals should be defined more widely than shareholders profits (Keasey et al, 1997). Therefore, corporate goals should include the legitimate interests of all relevant stakeholders in the important operational and strategic decisions the company makes (Barringer and Harrison, 2000). Waterhouse and Svendsen (1998) also endorse the importance of corporate strategy to be defined in terms of how the company will manage the contracts it has with its key stakeholders

As organizations attempt to compete successfully in the information era, they are turning to a variety improvement programs to enable them to adopt environmental changes. However, Kaplan and Norton (1996) argue that such programs should not be fragmented and need to be linked to the organization's strategy and to specific financial and economic outcomes. Therefore, the PM system needs improvements to incorporate multiple business aspects, in order to broaden the company's focus in an environment governed by broader interests. 
Several PM models have been developed that could be considered as improvements on the traditional-financial models. Some of these models can be categorized as 'shareholder value measurement models'. Three among these models are (a) Shareholder Value Analysis (SVA) proposed by Alfred Rappaport, (b) Economic Value Added (EVA) developed by Stern Stewart \& Co., and (c) Total Shareholder Return (TSR) and Total Business Return (TBR) developed by the Boston Consulting Group (Barbera and Coyte, 1997). These models are very much finance-related and take the position that business processes' ultimate success can be viewed through focussing on financial performance measures (Broadbent, 1999). However, the proposers of these models claim that traditional accounting methods and the shareholder value methodologies vary in complexity (Barbera and Coyte, 1997). Therefore, it might be argued that these models are still in the first (core) domain of performance measurement, the domain of financial performance, which emphasizes the importance of maximizing shareholder value.

The other improved models are the 'environmental-related PM models' (Broadbent, 1999). These have been claimed to consider the company's environment, particularly stakeholders, as an increasingly important aspect of management practice. Two among these models are (a) the Balance Scorecard (BSC), proposed by Kaplan and Norton, and (b) the Strategic Performance Measurement (SPM), proposed by Atkinson, Waterhouse and Wells. The BSC has become widespread, integrating stakeholder groups while considering both longterm and short-term perspectives and the internal business processes quite specifically (Olve et al, 2000; Broadbent, 1999). Its proposers have claimed the SPM model as 'a comprehensive measurement system' that is based on a stakeholder approach, and em- phasizes "a mix of learning-appropriate and decision-relevant financial and non-financial measures" (Waterhouse and Svendsen, 1998, p.5).

Both the shareholder-value measurement and the environmental related PM models seem to correspond with the increasing needs of an appropriate PM system. This innovation clearly requires a major shift in the mind-set of managers about managing organizations. Consequently, managers have to develop and articulate strategies more carefully, treat the organization as an integrated and co-ordinated set of activities, and link the strategy to performance.

\section{STRATEGIC MANAGEMENT: A STAKEHOLDER PERSPECTIVE Stakeholder Theory}

Since the 1960s, the conceptual revolution in the discipline of management has given rise to concerns regarding how the organization's executives manage an increasing number of external forces and pressures (Freeman, 1983). Since then, the concept of 'stakeholder' has grown in importance and "it takes a place at the center of the strategic management paradigm" (Freeman, 1983, 32). As a result, the interests of the company's stakeholders should be taken into consideration in designing strategies.

The term 'stakeholder' in a business context was introduced by the Stanford Research Institute in 1963 and was originally defined as "those groups without whose support the organization would cease to exist" (Freeman, 1983, p.33; Mitchell et al, 1997, p.854). This word can also be defined as "any group or individual who can affect or are affected by the achievement of the organization's objectives" (Barringer and Harrison, 2000, p.376). Based on this definition, an organization's stakeholders have two characteristics (Atkinson, 1998, p.554); (a) they affect the organization's ability to achieve its objectives, and (b) they require 
something in return for helping the organization to achieve its objectives.

Mitchell et al (1997) argue that there is not much disagreement on what kind of entity can be a stakeholder. They believe that "persons, groups, neighbourhoods, organizations, institutions, societies, and even the natural environment" are generally thought to qualify as actual or potential stakeholders (p.855). However, the groups typically cited as stakeholders include customers, suppliers, employees, local communities, government and shareholders (Berman et al, 1999; Hill and Jones, 1992). Each of these groups can be seen as supplying the firm with critical contributions and in exchange each expects its interests to be satisfied. Therefore, Barringer and Harrison (2000) view the relationship between an organization and its stakeholders as an 'inter-organizational relationship' through alliances that could help firms to create value.

An organization has been defined as 'a nexus of contracts' (Jensen and Meckling, 1976; Fama and Jensen, 1983). Such contracts specify or imply what an organization expects from each stakeholder group to help it to achieve its primary objectives, and what each stakeholder expects from the organization in return for participation (Shleifer and Vishny, 1997). Within this context, the role of PM is to monitor the give and take expressed or implied by each of these contracts. Therefore, it might be argued that one of the most important managerial functions is to establish and maintain stakeholder relationships to achieve the company's objectives. As a result, the stakeholder's capacity, opportunity, and willingness to threaten or cooperate must be considered in designing and implementing the company's strategy.

From the point of view of contractual relationships, an important factor in the survival of organizational forms is "the ability of a corporation to maintain its interdependent relationships with its key stakeholders" (Waterhouse and Svendsen, 1998, p.25). Thus, the central notion of the corporation from this perspective is that companies are engaged in an interdependent, symbiotic relationship with their stakeholders (Sternberg, 1997). This means that companies cannot avoid stakeholder relationships because every organization is dependent on its stakeholders. Therefore, one might argue that, in decision-making processes and in designing its strategies, the company should accommodate the impact of decisions on the company's relationship with its stakeholders as well. In turn, the choices the company makes in strategic planning must direct and inform the design of the PM system (Atkinson et al, 1997).

\section{Strategic Management and Stakeholder Approach}

Organizations have stakeholders. Therefore, in developing and implementing strategies every organization should consider those groups who can affect and are affected by an organization's objectives (Freeman, 1983). Accordingly, he (1983, p.43) argues that "the strategic management paradigm could be enhanced by including the stakeholder concept in its processes". Aside from its concrete applications as a framework for environmental analysis, Freeman believes that the basic philosophical issue of stakeholder approach in strategic management is a "thorough understanding of the effects of organization on its stakeholders". Additionally, by combining "an analysis of stakeholders, values and societal issues, executives can address the difficult question of the role of organization in society at large" (p.44). This process can be seen in figure 1 below. 


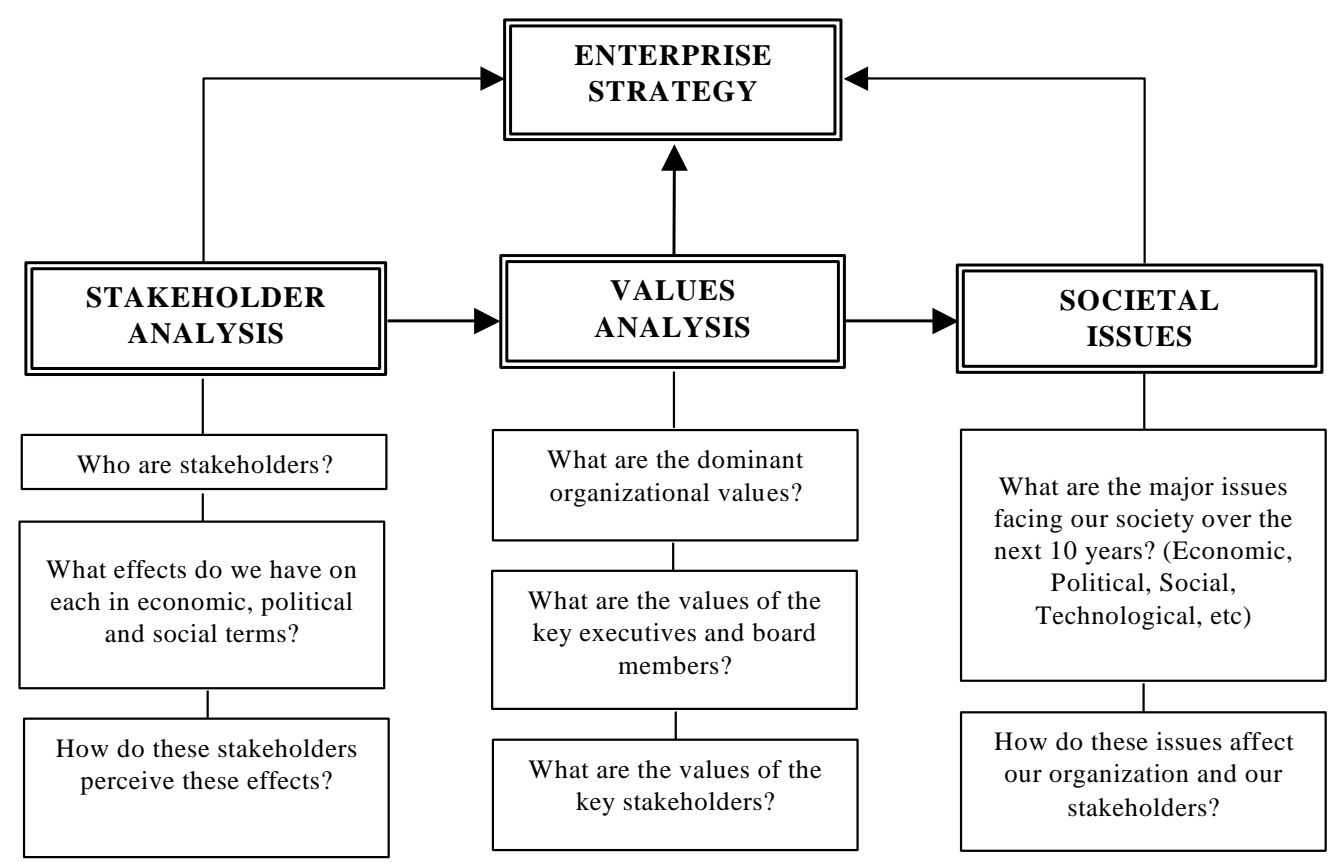

Source: Freeman (1983, p.45)

Figure 1: Enterprise-Level Strategy Process

According to Freeman (1983, p.38) the definition of 'stakeholder' implies that the strategic management process must include a method for mapping stakeholders and understanding the "stake" or potential influence of each group. This mapping is important for the company in order to recognize each category of stakeholder and their expectations from the company's operations. Additionally, in order for the stakeholder concept to be a useful addition to the strategic management paradigm, Freeman (1983) argues that it must be capable of yielding concrete descriptions and pragmatic categorizations of both stakeholder behavior and generic strategies for stakeholders. Therefore, he believes that through assessing stakeholder behavior at the corporate level, it will be possible to "enrich the understanding of the forces that shape competitive strategy" (p. 46).
The need to consider a broad range of stakeholders in formulating strategic directions has several implications for the strategic management paradigm (Freeman, 1983, p.39 - 41):

- The strategic task of environmental analysis must yield accurate descriptions of stakeholder behavior and must bound (not forecast) future behavior. Ultimately, the environmental analysis process must have a stakeholder-like concept

- The traditional analytical tools such as SWOT analysis, industry-company analysis etc, need to be rethought in terms of the business's ability to manage important stakeholder relationships. Hence, the successful company must take into account its relationships with multiple stakeholder groups and must 
understand the differential power and stake of each group.

- The stakeholder concept represents a generalization of many of the concepts currently in use. Thus, techniques, concepts, and research which can be used to understand customers and suppliers can also be applied to other stakeholders.

From the above-mentioned factors, one might argue that a firm's strategic management process for understanding the external environment can be improved by understanding its stakeholders. Therefore, the ability of the company to manage its relationships with multiple stakeholders and understand their differential powers can facilitate the company's achievement of its objective. Firms with good relationships with their stakeholders, on the basis of mutual trust and cooperation, will have a competitive advantage over firms that do not (Jones, 1995). Hence, there should be some recognition of the importance of stakeholder groups having long-term association with the company and, therefore, an interest in its long-term success.

However, the application of the stakeholder approach in strategic processes raises some important questions, particularly in relation to performance measures. The questions are (Freeman, 1983, p.53; Vinten, 2001,p.41):

- What are stakeholder interests and / or rights?

- What responsibility has the firm to each stakeholder's group?

- How do we measure how well an organization is doing with its stakeholders?

- What are the relevant variables?

- What are appropriate measures?

- What are appropriate measures of the relative power of suppliers, customers, government groups, and other stakeholders?
- How should we weigh the concerns of the least well off or least powerful stakeholders versus "wealthier" groups?

According to Freeman, the basic answers to these questions are the need for shifting from short-term financial measures to long-term social measures. He argues that appropriate measures should be able to balance the interests of a host of stakeholder groups, which can help managers to define the appropriate trade-offs to be made. Since there is no concrete answer to the operationalization of these measures, the development of adequate PM models poses challenges to management scholars.

\section{Identifying Stakeholder Group}

The main role of PM in strategic management is already obvious: it is to ensure that an organization pursues strategies that lead to the achievement of overall goals and objectives. Additionally, in order to survive in a dynamic environment, with the growing importance of stakeholders, companies have to maintain their networks with key stakeholders. Therefore, companies' abilities to align and balance their own interests with the interests of stakeholders are critical to achieve the company's objectives and also to reduce environmental uncertainty (Barringer and Harrison, 2000).

As a nexus of contracts, a company has both implicit and explicit contractual agreements with its stakeholders. Despite the fact that each stakeholder groups can be seen as supplying the firm with critical resources or contributions, they have different stakes in the firm (Hill and Jones, 1992). Hence, one could expect potential conflict of interests among various stakeholders, which may need to be resolved by the company.

The stakeholder perspective envisions organizations at the center of a network of stakeholders. However, most attention should be given to the legitimate inter- 
ests of the relevant and key stakeholders (Sternberg, 1997; Mitchell et al, 1997; Savage et al, 1991). Thus, determining which stakeholders matter most will resolve the potential conflict of their multiple interests in designing the strategy. Consequently it requires appropriate PM models to measure the achievement of a company's objectives based on such a strategy (Barringer and Harrison, 2000).

However, before considering the PM system that is appropriate to accommodate the interest of a company's stakeholders, the issue of how to divide them must be addressed, because it is much easier for the company to treat their stakeholder as a 'limited grouping' rather than treating the broader concept as mentioned by Freeman. In addition, from the stakeholder perspective, all stakeholders cannot be considered equally important and there should be a way to determine which stakeholders matter most (Barringer and Harrison, 2000).

Much of the literature on stakeholders has focused on identifying primary and secondary stakeholders (Mitchell et al, 1997; Savage et al, 1991). The primary stakeholders are those who have formal, official, or contractual relationships and have a direct and necessary economic impact upon the organization. Secondary stakeholders are diverse and include those who are not directly engaged in the organization's economic activities but are able to exert influence or are affected by the organization (Savage et al, 1991, p.62). Therefore, there is a need to identify relevant stakeholders, using certain criteria so that none of them are excluded from management attention.

According to Sternberg (1997) there are three criteria that determine the groups of stakeholders: materiality, immediacy and legitimacy criteria, while Mitchell et al (1997) propose the following attributes: power, legitimacy, and urgency. Based on these criteria, these writers believe that the firm can determine specific stakeholder interests to be addressed and can focus its attention on these specified interests rather than a broad, societal definition of stakeholders. Hence, managers must devise strategies that will coordinate and balance the interests of these various groups (Harrison and Freeman, 1999; Barringer and Harrison, 2000).

\section{DISCUSSION: PERFORMANCE MEASUREMENT AND STAKEHOLDER APPROACH}

The stakeholder approach highlights the importance of taking stakeholder preference into account in every business process and focuses on overseeing relationships that are critical to an organization's success. The role of stakeholder theory is seen to extend past the formulation of strategy to the establishment of performance goals. Through maintaining close relationships and possibly alliances with key stakeholders, a company can expect long-term cooperation that will lead to mutual benefits. Hence, one could expect better performance of such a company in the future.

As a nexus of contracts, every company has contractual relationships with its stakeholders, who require companies to accommodate their interests. The stakeholder approach conceives of the set of relationships between the organization and its stakeholders as a nexus of contracts. Therefore, appropriate strategies, and hence PM systems, should incorporate the relationships that exist, in order to achieve the company's objectives. Since there are potential conflicts among various interested parties, companies should also balance these interests whilst basing business processes on the strategies that have been developed.

I agree with the arguments that finance-based measures alone are inadequate in assessing business performance. Howev- 
er, as has been argued by several researchers, such measures should be retained and expanded, since they are still important indicators for every PM system. Hence, it could be argued that non-financial (operational) indicators are not a substitute or replacement for financial indicators. Rather, they should be seen as a complement and enhancement to leading indicators of the financial measures in order to expand the traditional PM system. Therefore, it can be argued that the changing nature of any PM is towards a broader system that can accommodate the growing importance of other issues that cannot be covered by finance-based indicators alone. By linking both indicators to critical management activities (i.e. strategy), PM models can help companies to monitor and manage the implicit and explicit contracts they have with stakeholders. In summary, the role of PM is to monitor the give and take implied by each of these contracts.

Another issue regarding the need for an improved PM system, as a vital part of the changing nature of PM, is the importance of viewing PM not only as the measure of outcome but also to use its indicators as the drivers for future performance. Proponents of shareholder-value models also agree with the importance of the drivers of value for shareholders that were identified as return, cash flow and asset growth, which are all finance-related values. Although the proposers of the shareholder-value measurement have claimed that their models are different from traditional financialaccounting models, these models still use financial measurement as their leading indicators. All of these models still perceive the importance of the goal of creating shareholder value. Through the adoption of valuebased management, these models assume that the creation of value for its shareholders is fundamental to the success of any company.

On the other hand, the BSC model views operational measures as the drivers for future financial outcomes, whilst the SPM model perceives the secondary objectives as the drivers for the company to achieve primary objectives. Although the needs of stakeholders group other than shareholders are considered a secondary concern, at least both models have already included the importance of other stakeholders in their PM models. Besides, the BSC model for example, has introduced the importance to balance various interests within the company that should be reflected in the company's strategy. In addition, both models provide information that might be important and required by relevant stakeholders in the company

However, based on performance concepts by Venkatraman and Ramanujam (1986), it seems that improved PM systems, particularly the BSC and SPM which consider other stakeholders are still in the second domain (i.e. domain of financial and operational performance). According to Kald and Nilsson (2000), the use of financial and selected operational performance indicators, rather than overall organizational effectiveness, brings up the difficulty of translating non-financial measures into financial ones. One difficulty in implementing the SPM model, for example, is how to translate secondary objectives (i.e. customer satisfaction or quality of service) into measurable outcomes such as profit. In general, it can be argued that these problems arise from difficulties relating to management action and results. Therefore, major limitations on the use of broader-set performance indicators are contributed by its operationalization, availability of data, and any consideration in order not to lose the objective of performance measurement.

Moreover, there is a potential problem in considering diverse interests of stakeholders in the company's business processes. Although there is an approach to regrouping and mapping, in order to identify 
key stakeholders, it is still difficult to consider and treat them according to their just deserves. Because groups may have conflicting interests that may affect strategic implementation and, hence, could harm the achievement of the company's objectives, it might be argued that this factor is one consideration for the proposers of improved PM models not to consider all stakeholder groups in their models. This may be why the environmental-related models focus only on some aspects of performance relative to each stakeholder group.

The BSC model, for example, does not state explicitly that this model is based on the stakeholder approach nor does it take into account all the stakeholders mentioned by the theory. This model only implicitly considers several interests that are: customers, suppliers, and employees (in terms of innovation and learning perspectives). The SPM model, on the other hand, explicitly states that this model is based on the stakeholder approach. This model includes a much broader stakeholder base than the BSC: shareholders, customers, employees and community. However, both models have widened their scope of measurement to include stakeholder interests, although limited to certain groups. Additionally, both already recognize the importance of PM, not only to measure outcomes, but also as the drivers of future performance.

Other related issues to be considered in the improved PM systems include the importance of balance between various measures. The BSC model (Kaplan and Norton, 1996) for example, incorporates a balance between:

- External measures for shareholders and customers, and internal measures of critical business processes, innovation, and learning and growth,

- The outcome measures - the results from past efforts - and the measures that drive future performance, and
- Short-term performance via financial measures and the value drivers for superior long-term financial and competitive performance.

Therefore, one of the most important roles of balanced PM is that it makes a systematic attempt both to measure those relationships and communicate them to operating managers, and provides a basis for organizations learning about those relationships (Atkinson and Epstein, 2000).

Unlike the shareholder-value measurement models, both the BSC and SPM models of performance have recognized the importance of stakeholders in the business process. However, it can be seen that both models still emphasize the financial indicators from the fact that these indicators take place as primary goals (the BSC) and primary measures (the SPM). Other non-financial (operational) indicators are treated as secondary goals or measures, which are viewed as the drivers of the primary goals or primary measures. Therefore, it can be argued that those secondary goals or measures are instrumental in helping the company achieve its primary objectives in both models.

Another problem in the implementation of PM is that various models cannot be generalized and should be tailored to specific industries where the company operates. Additionally, it might be difficult to apply this kind of model in very large corporations (such as IBM) that might have thousands of stakeholders. Although grouping and identifying key stakeholders is possible for IBM, the problem may be how to treat every member of the group of suppliers (as company's stakeholders) equally, because all of them can be considered important. 


\section{IMPLICATIONS FOR FUTURE RESEARCH}

On the basis of the issues that have been discussed in this paper, one can envision refinements in long-standing PM systems designed to assist managers in dealing with a more complex company environment. Presently, PM systems which place emphasis on the stakeholder are being utilized to help managers deal effectively with multiple stakeholder relationships. Current PM models, particularly the environmental-related models, include identification of stakeholder roles within companies. Through the stakeholder approach, the set of relationships between the organization and its stakeholders are being articulated as a nexus of implicit and explicit contracts. Therefore, the role of PM from this point of view is to monitor the give and take expressed or implied by each of these contracts.

PM models that incorporate and balance various stakeholder interests within the company have the potential to improve upon current practice. They hold the key to more effective management and to a more useful, comprehensive theory of the firm in the society. Focusing attention on salience in the company-stakeholder relationships existing in a firm's environment appears to be a productive strategy for future research in developing appropriate PM system. The PM models, therefore, must reflect "the complexity of business today, and the heightened requirement for world-class performance in far more aspects of corporate operations - from emphasizing innovation to fostering diversity" (Atkinson and Epstein, 2000, p.28).

In relation to PM models that take into account the important relationships with the company's stakeholders, there is a need for empirical research that answers these questions:

- How to develop the framework that could identify the company's perfor- mance variables that best reflect its relationship with its key stakeholders?

- How to design a PM system that is tailored to meet the needs of each company's business and could be expanded to take into account the critical stakeholder relationships the firms depend on to prosper?

- How could different organizations connect together all of the financial and non-financial measures in a coherent and comprehensible manner?

- How to formalize the inclusion of empowered stakeholder groups that may have no formal representation in the organization?

Finally, since the pressure exerted by the organization's stakeholders influences the performance goals set by a manager, it will have an affect in designing the company's strategy. Therefore, in attempting to develop an appropriate PM system based on the stakeholder approach, the said PM should be linked and driven by strategy.

\section{CONCLUSION}

In a dynamic environment with increasing importance on contractualrelationships with its stakeholders, companies are required to consider these groups in their business processes. As a result, the company must introduce and maintain new ways of managing its relationships as well as measuring business performance, including various stakeholders' interests. This view shifts the importance of maximizing the single most important shareholders, towards the company's accountability to a more diverse group of stakeholders.

Several models, including the BSC and the SPM, have been introduced in response to these needs which can be categorized as a part of the second domain of performance measurement. Neither model, however, considers all stakeholder groups, 
treating some of them as only secondary and as an instrument to achieve primary goals. Primary goals for both models are still the shareholder group, emphasizing the importance of financial indicators as measures of residual claims for the company's shareholders. Thus, other stakeholder groups, which are considered a secondary concern, are seen as drivers of future financial performance. In general, these models foresee that improvement of secondary measures will result in improved future performance.
Although improved PM has taken the stakeholders into consideration, one might argue that financial measures still continue to be the end measures of a company's performance. A major problem in the implementation of PM models that have broadened their indicators of measurement to include other non-financial (operational) indicators is in their operationalization. Therefore, the overall appropriateness of a PM system is important, as well as the benefits it might be contribute to the achievement of the company's objectives.

\section{REFERENCES}

Atkinson, A.A. (1998) 'Strategic Performance Measurement and Incentive Compensation' European Management Journal, Vol.16, No. 5, pp.552-561

Atkinson, A.A., and Epstein, M. (2000) 'Measure for Measures; Realizing the Power of the Balance Scorecard' CMA Management, September

Atkinson, A.A., Waterhouse, J.H. and Wells, R.B. (1997) 'A Stakeholder Approach to Strategic Performance Measurement' Sloan Management Review, Spring, pp.25-37

Banker, R.D., Chang, H., and Majumdar, S.K. (1991) 'A Framework for Analyzing Changes in Strategic Performance’ Strategic Management Journal, Vol.17, pp.693-712

Barbera, M.R. and Coyte, R.W. (1997) 'Shareholder Value Demystified: an Explanation of Methodologies and Use' Working Papers the University of New South Wales

Barringer, B.R., Harrison, J.S. (2000) 'Walking a Tightrope: Creating Value Through Interorganizational Relationships' Journal of Management, Vol. 26, No.3, pp.367-403

Berman, S.L., Wicks, A.C., Kotha, S., and Jones, T.M. (1999) 'Does Stakeholder Orientation Matter? The Relationship Between Stakeholder Management Models and Firm Financial Performance' Academy of Management Journal, Vol.42, No.5, pp.488-506

Brignall, S., Ballantine, J. (1996) 'Performance Measurement in Service Business Revisited' International Journal of Service Industry Management, Vol. 7, No. 1, pp.6-31

Broadbent, M. (1999) 'Measuring Business Performance', CIMA Publications, London.

Chakravarthy, B.S. (1986) 'Measuring Strategic Performance' Strategic Management Journal, Vol. 7, pp.437-458

Chow, C.W., Haddad, K.M., and Williamson, J.E. (1997) 'Applying the Balance Scorecard to Small Companies', Management Accounting, August, pp.21-27

Dent, J. F. (1996) 'Global Competition: Challenges for Management Accounting and Control' Management Accounting Research, No. 7, pp. 247 -269 
Dixon, J.R., Nanni, A.J. and Vollmann, T.E. (1990) 'The New Performance Challenge; Measuring Operations for World Class Competition', Irwin, Homewood

D’Souza, D.E. and Williams, F.P. (2000) 'Appropriateness of The Stakeholder Approach to Measuring Manufacturing Performance' Journal of Management Issues, Vol. 12, No.2, pp.227-246

Eccles, R. G., (1991) 'The Performance Measurement Manifesto' Harvard Business Review, January-February, pp.131-137

Eccles, R.G., and Pyburn, P.J. (1992) 'Creating a Comprehensive System to Measure Performance' Management Accounting, October, pp.41-44.

Epstein, M.J., Manzoni, J.F. (1997) 'The Balance Scorecard and Tableau de Bord: Translating Strategy Into Action' Management Accounting, August, pp.28-36

Fama, E. F., Jensen, M. C. (1983) 'Agency Problems and Residual Claims' Journal of Law and Economics, Vol. XXVI, pp.327-349

Freeman, R.E. (1983) 'Strategic Management: a Stakeholder Approach' in Lamb, R (ed.) Advances in Strategic Management, Vol.1, pp.31-60

Gaiss, M. (1998) 'Enterprise Performance' Management Accounting, December, pp.44-46

Ghalayani, A.A., Noble, J.S. (1996) 'The Changing Basis of Performance Measurement' International Journal of Operations \& Production Management, Vol.16, No. 8, pp.63-80

Harrison, J.S. and Freeman, R.E. (1999) 'Stakeholders, Social Responsibility, and Performance: Empirical Evidence and Theoretical Perspectives' Academy of Management Journal, Vol. 42, No.5, pp.479-485

Hill, C.W.L., Jones, T.M. (1992) 'Stakeholder-Agency Theory' Journal of Management Studies, Vol. 29, No. 2, pp.127 -154

Jensen, M.C., Meckling, W.H. (1976) 'Theory of the Firm: Managerial Behavior, Agency Costs and Ownership Structure' Journal of Financial Economics, Vol. 3, pp. 305360

Jesuthasan, R., Todd. E. and Barret, A. (2000) 'The Total Performance Equation' Financial Executive, Vol. 16, No.4, pp.41-44

Jones, T.M., (1995) 'Instrumental Stakeholder Theory: a Synthesis of Ethics and Economics' Academy Management Review, Vol. 20, No. 2, pp.404-437

Kald, M., Nilsson, F., (2000) 'Performance Measurement At Nordic Companies' European Management Journal, Vol. 18, No. 1, pp.113-127)

Kaplan, R.S., Norton, D.P. (1992) 'The Balance Scorecard-Measures That Drive Performance' Harvard Business Review, January-February, pp.71-79

Kaplan, R.S., Norton, D.P. (1996) 'The Balance Scorecard; Translating Strategy into Action' Harvard Business School Press, US. 
Keasey, K., Moon, P., and Duxbury, D. (2000) 'Performance Measurement and the Use of League Tables: Some Experimental Evidence of Dysfunctional consequences' Accounting and Business Research, Vol. 30, No. 4, pp.275-286

Mcnair, C.J., Lynch, R., and Cross, K. F. (1990) 'Do Financial and Non-financial Measures Have to Agree?' Management Accounting, November, pp.28-36

Meyer, M.W., Gupta, V. (1994) 'The Performance Paradox' Research in Organizational Behavior, Vol.16, pp.309-369

Mitchell, R.K., Agle, B.R. and Wood, D. J. (1997) 'Toward a Theory of Stakeholder Identification and Salience: Defining the Principle of Who and What Really Counts' Academy of Management Review, Vol. 22, No. 4, pp.853-886

Olve, N.G., Roy, J., Wetter, M. (2000) 'Performance Drivers; Practical Guide to Using the Balance Scorecard' John Wiley \& Sons Ltd., Chichester

Rhyne, L.C. (1986) 'The Relationship of Strategic Planning to Financial Performance' Strategic Management Journal, Vol.7, pp.423-436

Rummler, G.A., Brache, A.P. (1995) 'Improving Performance: How to Manage the White Space on the Organization Chart' Jossey-Bass Inc., California

Savage, G.T., Nix, T.W, Whitehead, C.J. and Blair, J.D. (1991) 'Strategies for Assessing and Managing Organizational Stakeholders' Academy of Management Executive, Vol. 5, No. 2, pp.61-75

Shleifer, A., Vishny, R.W. (1997) 'A Survey of Corporate Governance' The Journal of Finance, Vol. LII, No.2, pp.737-783

Sternberg, E. (1997) 'The Defects of Stakeholder Theory' International Journal of Corporate Governance, Vol.5, No.1, pp.3-10

Tatikonda, L.U., Tatikonda, R.J. (1998) 'We Need Dynamic Performance Measures' Management Accounting, September, pp.49 -53

Venkatraman, N., Ramanujam, V. (1986) 'Measurement of Business Performance in Strategy Research: a Comparison of Approaches' Academy of Management Review, Vol.11, No.4, pp.801-814

Vinten, G. (2001) 'Shareholder versus Stakeholder-is there a governance dilemma?' Corporate Governance: An International Review, Vol.9, No.1, pp.36-47

Waddock, S. A., Graves, S. B. (1997) 'The Corporate Social Performance-Financial Performance Link' Strategic Management Journal, Vol. 18:4, pp. 303-319

Waterhouse, J., Svendsen, A. (1998) 'Strategic Performance Monitoring and Management: Using Non-Financial Measures to Improve Corporate Governance', CICA, Ontario 


\section{Appendix 1}

\section{Critics of Traditional Financial-based Performance Measurement}

\begin{tabular}{|c|c|}
\hline Author (s) & Limitations of financial indicators \\
\hline $\begin{array}{l}\text { Kald and Nilsson } \\
\text { (2000) }\end{array}$ & $\begin{array}{l}\text { Concentrate too much on the past; focus excessively on the short run; over } \\
\text { emphasize the financial aspects of businesses }\end{array}$ \\
\hline $\begin{array}{l}\text { Waterhouse and } \\
\text { Svendsen (1998) }\end{array}$ & $\begin{array}{l}\text { Inadequate for managing and controlling companies; fail to capture im- } \\
\text { portant aspects or organizational performance; inadequate in an economy } \\
\text { where intangible assets and ongoing relationships between companies and } \\
\text { their stakeholders create value; dealing with the past }\end{array}$ \\
\hline $\begin{array}{l}\text { Kaplan and Norton } \\
\text { (1992) }\end{array}$ & $\begin{array}{l}\text { Out of step with the skills and competencies companies are trying to master } \\
\text { today; did not fit with the engineering mentality of industrial age; can give } \\
\text { misleading signals for continuous improvement and innovation-activities in } \\
\text { today's competitive environment demand }\end{array}$ \\
\hline $\begin{array}{l}\text { Atkinson, Waterhouse } \\
\text { and Wells (1997) }\end{array}$ & $\begin{array}{l}\text { Ignorant of the claims of other stakeholders; lack the focus and robustness } \\
\text { needed for internal management and control }\end{array}$ \\
\hline Chakravarthy (1986) & $\begin{array}{l}\text { Emphasis on the satisfaction of shareholders; scope for accounting manipu- } \\
\text { lation; undervaluation of assets }\end{array}$ \\
\hline Eccles (1991) & $\begin{array}{l}\text { Better at measuring the consequences of yesterday's decision than they are } \\
\text { at indicating tomorrow's decision; provides no information on poor service } \\
\text { or deficient quality, for example, until these problems show up in the in- } \\
\text { come statement }\end{array}$ \\
\hline Rhyne (1986) & Capture only a portion of the firm's effectiveness \\
\hline $\begin{array}{l}\text { Epstein and Manzoni } \\
\text { (1997) }\end{array}$ & $\begin{array}{l}\text { Capture the impact of decisions with a significant time lag and tend to be } \\
\text { less proactive indicators of potential problems }\end{array}$ \\
\hline $\begin{array}{l}\text { Brignall and Bal- } \\
\text { lantine (1996) }\end{array}$ & $\begin{array}{l}\text { Failure to measure and monitor multiple dimensions of performance (be- } \\
\text { cause organizational success also depends on how well the organization } \\
\text { adapts to the environment within which it exists) }\end{array}$ \\
\hline $\begin{array}{l}\text { Keasey, Moon and } \\
\text { Duxbury (2000) }\end{array}$ & $\begin{array}{l}\text { Masks the means by which the performance was achieved; can be manipu- } \\
\text { lated to someone's own interest }\end{array}$ \\
\hline $\begin{array}{l}\text { Ghalayani and Noble } \\
\text { (1996) }\end{array}$ & $\begin{array}{l}\text { Have not incorporated strategy; try to quantify performance and other im- } \\
\text { provement efforts in financial terms; had the effect of setting norms rather } \\
\text { than motivating improvement }\end{array}$ \\
\hline $\begin{array}{l}\text { Eccles and Pyburn } \\
\text { (1992) }\end{array}$ & $\begin{array}{l}\text { Financial indicators cannot provide much guidance for what must be done } \\
\text { differently; internal rather than external focus }\end{array}$ \\
\hline
\end{tabular}




\section{Appendix 2}

\section{Reasons to Consider the Changes in Performance Measurement}

\begin{tabular}{|c|c|}
\hline Author (s) & The need for improved performance measurement \\
\hline $\begin{array}{l}\text { Waddock and Graves } \\
\text { (1997) }\end{array}$ & $\begin{array}{l}\text { The complexity of strategic decision-making as the result of the impact of } \\
\text { different stakeholder expectations }\end{array}$ \\
\hline $\begin{array}{l}\text { Kaplan and Norton } \\
\text { (1992) }\end{array}$ & $\begin{array}{l}\text { There is no single measure that can provide a clear performance target of } \\
\text { focus attention on the critical areas of the business; managers want a bal- } \\
\text { anced presentation of both financial and operational measures }\end{array}$ \\
\hline Eccles (1991) & $\begin{array}{l}\text { The leading indicators of business performance cannot be found in finan- } \\
\text { cial data alone; pressure from efforts to generate measures of customer } \\
\text { satisfaction }\end{array}$ \\
\hline $\begin{array}{l}\text { Epstein and Manzoni } \\
\text { (1997) }\end{array}$ & $\begin{array}{l}\text { There is no single performance indicator that can capture the full com- } \\
\text { plexity of an organization performance; the need to balance the focus on } \\
\text { other stakeholders }\end{array}$ \\
\hline $\begin{array}{l}\text { Atkinson, Waterhouse } \\
\text { and Wells (1997) }\end{array}$ & $\begin{array}{l}\text { The need for business performance that specifies relationships between } \\
\text { the company and its various stakeholders }\end{array}$ \\
\hline Chakravarthy (1986) & $\begin{array}{l}\text { The ability to measure satisfaction of all of the firm's stakeholders is an } \\
\text { important discriminators of strategic performance }\end{array}$ \\
\hline $\begin{array}{l}\text { Berman, Wicks, Kotha } \\
\text { and Jones (1999) }\end{array}$ & $\begin{array}{l}\text { Broadening the definition of performance may allow better understanding } \\
\text { the important links amongst stakeholder relationships, strategy and per- } \\
\text { formance }\end{array}$ \\
\hline $\begin{array}{l}\text { Waterhouse and } \\
\text { Svendsen (1998) }\end{array}$ & $\begin{array}{l}\text { The broader and more strategically performance measures and a system } \\
\text { for integrating performance information into critical business decisions } \\
\text { and activities are required }\end{array}$ \\
\hline $\begin{array}{l}\text { Keasey, Moon and } \\
\text { Duxbury (2000) }\end{array}$ & There is a need to evaluate performance across wide range of dimensions \\
\hline $\begin{array}{l}\text { Tatikonda and Tatik- } \\
\text { onda (1998) }\end{array}$ & Performance measures need to reflect the changes in competitiveness \\
\hline $\begin{array}{l}\text { Banker, Hsi-Hui and } \\
\text { Majumdar (1996) }\end{array}$ & $\begin{array}{l}\text { The need for aggregate measures of performance that do not confound the } \\
\text { impact of different strategic factors }\end{array}$ \\
\hline $\begin{array}{l}\text { Eccles and Pyburn } \\
\text { (1992) }\end{array}$ & $\begin{array}{l}\text { The extension on traditional financial measures are needed in response to } \\
\text { changing markets, new strategies, and concerns about a "short-term orien- } \\
\text { tation" }\end{array}$ \\
\hline
\end{tabular}


SIIERGH Vol. 10 No. 2, JUNI 2008: 179 - 198

Appendix 3

Aspects to be considered in the Improved Performance Measurement

\begin{tabular}{|c|c|}
\hline Author (s) & Aspects to be considered \\
\hline $\begin{array}{l}\text { Kald and Nilsson } \\
\text { (2000) }\end{array}$ & $\begin{array}{l}\text { Further improvement in performance measurement is important in such } \\
\text { areas as quality, reliability of delivery, lead times, and customer satisfac- } \\
\text { tions that are all required by all stakeholders in the company }\end{array}$ \\
\hline $\begin{array}{l}\text { Meyer and Gupta } \\
\text { (1994) }\end{array}$ & $\begin{array}{l}\text { Multiple and disparate performance measures to accommodate diverse } \\
\text { interests among stakeholders }\end{array}$ \\
\hline $\begin{array}{l}\text { Kaplan and Norton } \\
\text { (1992) }\end{array}$ & $\begin{array}{l}\text { The need of operational performance that are the drivers of future finan- } \\
\text { cial performance; measurement which links and balanced strategy and } \\
\text { operations }\end{array}$ \\
\hline $\begin{array}{l}\text { Keasey, Moon and } \\
\text { Duxbury (2000) }\end{array}$ & $\begin{array}{l}\text { Performance indicators that may prevent dysfunctional behavior such as } \\
\text { manipulation of indicators according to personal interest }\end{array}$ \\
\hline $\begin{array}{l}\text { Epstein and Manzoni } \\
\text { (1997) }\end{array}$ & $\begin{array}{l}\text { Performance indicators that are considered to be strategy's key success } \\
\text { factors; Proactive to enable management monitor corporate progress }\end{array}$ \\
\hline $\begin{array}{l}\text { Tatikonda and Tatik- } \\
\text { onda (1998) }\end{array}$ & $\begin{array}{l}\text { Should reflect the changes in competitiveness and balance short-term and } \\
\text { long-term measures, internal and external measures, financial and non- } \\
\text { financial measures }\end{array}$ \\
\hline $\begin{array}{l}\text { Waterhouse and } \\
\text { Svendsen (1998) }\end{array}$ & $\begin{array}{l}\text { Measurement indicators which are adequate in an economy where intan- } \\
\text { gible assets and ongoing relationships between companies and stakehold- } \\
\text { ers creates value }\end{array}$ \\
\hline $\begin{array}{l}\text { Waddock and Graves } \\
\text { (1997) }\end{array}$ & $\begin{array}{l}\text { Companies' performances should measure up to a broader set of societal } \\
\text { expectations }\end{array}$ \\
\hline Chakravarthy (1986) & $\begin{array}{l}\text { Indicators with the inclusion of transformation processes within the firm } \\
\text { and that consider the claims of stakeholders }\end{array}$ \\
\hline Gaiss (1998) & $\begin{array}{l}\text { Performance indicators that enable people to communicate and provide } \\
\text { feedback on performance against objective }\end{array}$ \\
\hline $\begin{array}{l}\text { Atkinson, Waterhouse } \\
\text { and Wells (1997) }\end{array}$ & $\begin{array}{l}\text { Performance measurement that can accommodate organizational learning } \\
\text { and gives a way to evaluate contribution of the company's suppliers }\end{array}$ \\
\hline $\begin{array}{l}\text { Harrison and Freeman } \\
\text { (1999) }\end{array}$ & $\begin{array}{l}\text { Refocusing performance measurement on a broad set of stakeholder rela- } \\
\text { tionships rather than a narrow set of purely economic relationship }\end{array}$ \\
\hline $\begin{array}{l}\text { Mcnair, Lynch and } \\
\text { Cross (1990) }\end{array}$ & $\begin{array}{l}\text { Measurement systems should be; strategic focus, systematically opti- } \\
\text { mised, integrated and provides organization learning through group incen- } \\
\text { tives }\end{array}$ \\
\hline $\begin{array}{l}\text { Eccles and Pyburn } \\
\text { (1992) }\end{array}$ & $\begin{array}{l}\text { Performance measurement systems should broadened to include quality, } \\
\text { customer satisfaction, innovation \& similar results }\end{array}$ \\
\hline
\end{tabular}

